\title{
KÖNNYŰ SPORTREPÜLŐGÉP TERVEZÉSE SZÉLCSATORNA TESZTEK ÉS KORSZERÜ TERVEZŐPROGRAMOK ALKALMAZÁSÁVAL
}

\section{CONCEPTUAL DESIGN OF A LIGHT SPORT AIRCRAFT WITH EMPHASIS ON WIND TUNNEL TESTS AND SOFTWARE TOOLS}

\author{
Angi Norbert ${ }^{1}$, Răzvan Udroiu ${ }^{2}$, Angel Huminic ${ }^{3}$ \\ ${ }^{1}$ Transilvania Egyetem, Mekanikai Mérnöki Kar, Repülő Mérnöki Szakképzés, \\ Cím: 500017, Románia, Brassó, Telefon 0753112470,anginorbert@gmail.com \\ ${ }^{2}$ Transilvania Egyetem, Repülö Mérnöki Kar, udroiu.r@unitbv.ro \\ ${ }^{3}$ Transilvania Egyetem, Folyadekok Mekankája Tanszék, angel.h@unitbv.ro
}

\begin{abstract}
This paper presents the preliminary design of a light sport aircraft (LSA), based on multiple design phases and wind tunnel tests, in order to obtain new lightweight, low cost, low fuel consumption and long-range aircraft. A series of wind tunnel tests were taken in order to improve the aerodynamic calculations of the concept airplane. The preliminary design and wind tunnel tests will follow a series of flight experiments to determine the real performance and dynamic stability of the airplane.
\end{abstract}

Keywords: conceptual aircraft design, flight envelope diagram, aerodynamics, wind tunnel tests, aerodynamic balance calibration.

\section{Összefoglalás}

Jelen tanulmányi anyag egy könnyüszerkezetes sportrepülőgép (LSA) előzetes tervezését mutatja be kitérve ennek különböző tervezési fázisaira, illetve szélcsatorna kísérleteire - amely különös figyelmet fordít egy könnyűszerkezetü, nagy hatótávolságú, alacsony üzemanyagfogyasztású, illetve kis költségvetésű repülőgép gyártására. Számos szélcsatorna-teszt végrehajtására került sor, a repülőgép aerodinamikai számításainak fejlesztésére. Az előzetes tervezési számításokat, illetve a szélcsatorna kísérleteket sorozatos repülési kísérletek követik, amik segítségével meghatározhatjuk a repülő valós teljesítményét és dinamikai stabilitását.

Kulcsszavak: koncepciós repülőgép-tervezés, repülési diagram, aerodinamika, szélcsatornakisérletek, kalibrációs mérések.

\section{Bevezetés}

A tanulmány fó célja, hogy bemutasson egy olyan koncepciós könnyü vázszerkezetes sportrepülögépet (LSA) - kezdve a kezdetleges tervezési tanulmányoktól a szélcsatorna tesztekig - melynek aerodinamikai teljesítménye 15\%-al-, üzemanyag fogyasztása $12.42 \%$-al- és repülési hatótávolsága $10 \%$-al meghaladja a jelenlegi piacon lévő, ugyanebbe a kategóriába tarto- 
zó könnyü sportrepülőgépek teljesít-ményét (pl. Flight Design CTLSi, Czech Sport Aircraft, Evektor Harmony). Mindezt versenyképes elöállítási költségen (költségtartomány $100.000-140.000 €$ ).

\subsection{Fő célkitúzések}

A fő célkitüzések:

- egy 1/10 mértékarányú repülömodell szélcsatorna kísérletei;

- egy 1/4 mértékarányú kísérleti repülögép repülési tesztjei, hasonlósági számítások alkalmazásával;

- a repülögép teljesítményének meghatározása és gyártási előkészületei.

1. táblázat. - A repülögép általános jellemzöi

\begin{tabular}{|c|c|}
\hline Paraméterek & \\
\hline személyzet & 1 pilóta \\
\hline kapacitás & 1 utas \\
\hline hossz & $6.45 \mathrm{~m}$ \\
\hline szárnyfelület & $11.5 \mathrm{~m} 2$ \\
\hline szárnyfesztáv & $10.2 \mathrm{~m}$ \\
\hline szárnyprofil & Eppler 562 \\
\hline minimális tömeg & $315 \mathrm{~kg}$ \\
maximális felszállási tömeg & $600 \mathrm{~kg}$ \\
\hline üzemanyag tartály & $100 \mathrm{~L}$ \\
\hline motor & Rotax $912 \mathrm{iS}$ \\
\hline maximális sebesség & $275 \mathrm{~km} / \mathrm{h}$ \\
utazási sebesség & $206 \mathrm{~km} / \mathrm{h}$ \\
\hline repülési hatótávolság & $1650 \mathrm{~km}$ \\
\hline repülési csúcsmagasság & $5500 \mathrm{~m}$ \\
\hline
\end{tabular}

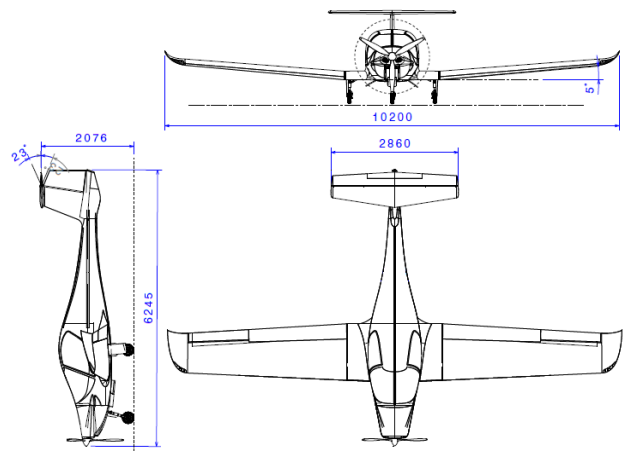

1. ábra. A repülőgép fentről, szemböl és oldalnézetböl
A repülő előzetes tervezése: Raymer 1992, Jenkinson 1999, Roskam 1985, Torenbeek 1982, Nicolai 1975, Schaufele 2007 és Grosu 1965, repülö tervezési szakirodalmain alapszik. [2]

\section{V-n diagram (Maneuver \& Gust Diagram)}

A koncepciós repülőgép kezdetleges tervezése a CS-LSA (Certification Specification of Light Sport Aircraft [1]) követelményeire alapoz.

Annak érdekében, hogy meghatározzuk a repülő teljesítmény- és sebesség határait, manőver- és széllökés grafikonok felállitására volt szükség (V-n grafikon).

A repülögép manőverezhetőségi grafikonja szemlélteti az eltérő terhelési tényezők változását különböző repülési sebességek esetén. Alacsony sebességnél, a maximális terhelési tényező korlátozza a maximális felhajtóerő, CL értékét. Nagy sebességnél a manőverezési terhelési tényezőt a CS-LSA szabályzata korlátozza. A maximalis terhelési tényező $+3.8 \mathrm{~g}$ és az elöírt negatív terhelési érték $-1.5 \mathrm{~g}$. A terhelési tényezö értéke az utazási sebesség $(\mathrm{Vc})$, értékéig exponenciálisan nő, azt követően lineárisan csökken, elérve a maximális repülési sebességet (VD).

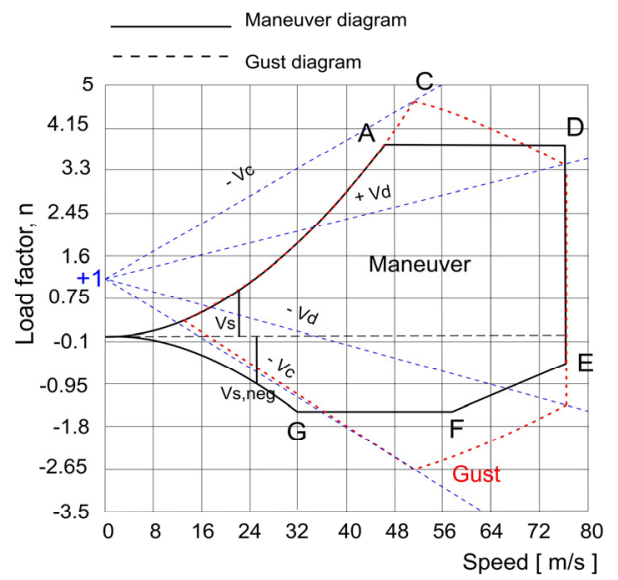

2. ábra. A repülögép V-n diagramja [7] 


\section{Szélcsatorna kísérletek}

A repülő szélcsatorna kísérletei a brassói Transilvania Egyetem aero-dinamikai laboratóriumában történtek. A szélcsatorna zárt kísérleti fülkéje $1.2 \mathrm{~m} \times 0.6 \mathrm{~m} \times 1.2 \mathrm{~m}$, a maximális tesztelési sebes-sége $40 \mathrm{~m} / \mathrm{s}$ és a turbulencia értéke kevesebb mint $0.5 \%$, amely megfelel az SAE (Society of the Automotive Engineers) elóirásoknak.

A szélcsatorna kísérleteket, pontosabb aerodinamikai eredmények elérése céljából egy $1 / 10$ mértékarányú repülőmodellen végeztük (lásd 3. ábra).

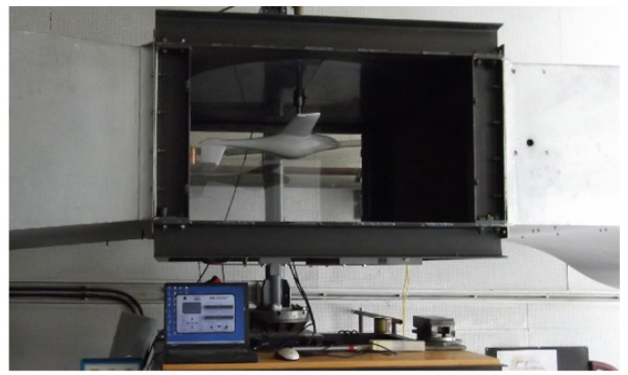

3. ábra. $A$ repülömodell a szélcsatorna zárt kísérleti fülkéjében

A szélcsatorna kísérleteket a tensziómetrikus müszerek kalibrálása előzte meg. A tensziómetrikus müszer kalibrációs eredményei az 4. és 5. ábrán láthatók. [5] Ezeken az adatfeldolgozó rendszer által mért felhajtóerő és légellenállás értékei (Lift \& Drag) szerepelnek, a repülőgép Ox, illetve $\mathrm{Oz}$ tengely terhelése függvényében.

$$
L=k_{L} F, \quad D=k_{D} F
$$

A kalibrációs méréseket követően a repülö-modell különböző állásszögeken $(\alpha)$ volt tesztelve.

A szélcsatorna vizsgálati kamrájában mért légköri paraméterek értékei a következök: hömérséklet $\mathrm{t}=26^{\circ} \mathrm{C}$; légnyomás $\mathrm{p}=94440 \mathrm{n} / \mathrm{m}^{2} ; \quad$ légsürüség $\rho=1.010$ $\mathrm{kg} / \mathrm{m}^{3}$; dinamikus viszkozitás $\mu=1.84 * 10^{-5}$ $\mathrm{kg} / \mathrm{ms}$.

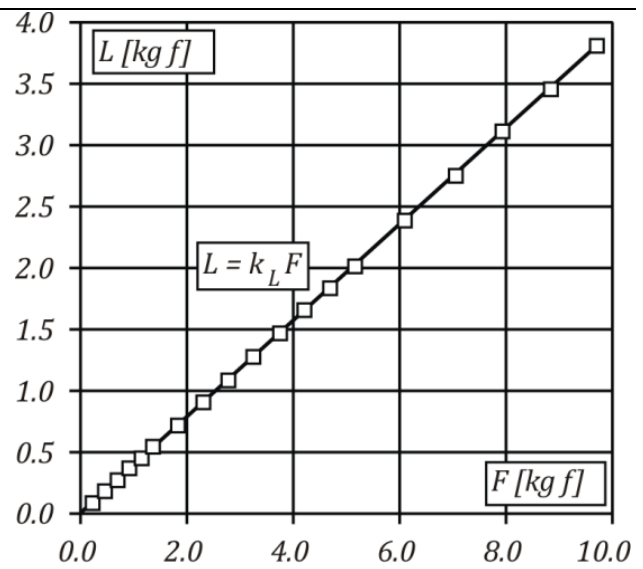

4. ábra. $A$ repülő $O z$ tengelye után mért kalibrációs grafikonja [3]

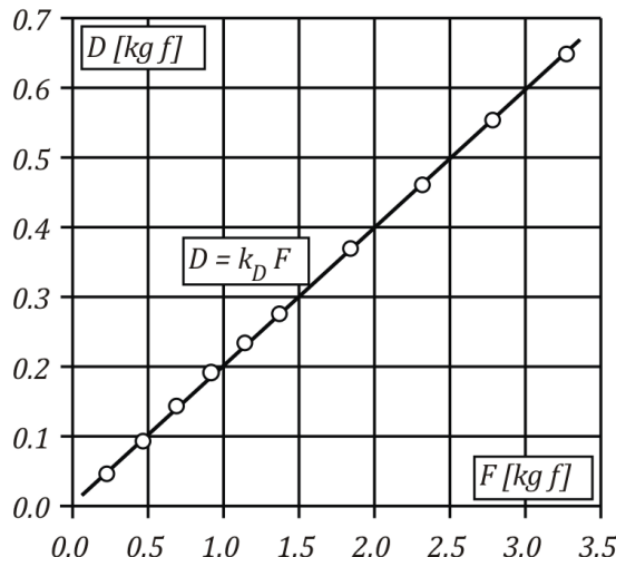

5. ábra. $A$ repülö $O x$ tengelye után mért kalibrációs grafikonja [3]

A szélcsatorna tesztek során mért Reynolds szám átlag értéke, adott MAC $=0.116$ $m$ érték esetén (Main Aerodynamic Chord), $\mathrm{Re}=2.17 * 105$.

A szélcsatorna kísérleteket egy sorozatos korrekciós számítás követte, a "William H., Low-speed wind tunnel testing " elmélete alapján: interferencia-, turbulens áramlások-, állásszög és légellen-állás-, dinamikus légnyomás korrekciós számítások [6].

A korrekciós szélcsatorna kísérletek és becsült számítógépes aerodinamikai eredmények a 6. ábrán követhetők. 


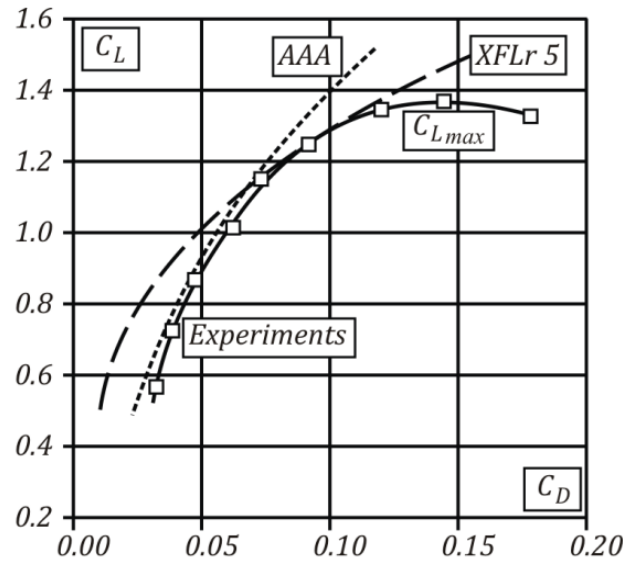

6. ábra. A repülö kisérleti és elméleti poláris görbéi [3].

a) $C L / C x$-felhajtóerő és légellenállás függvényében

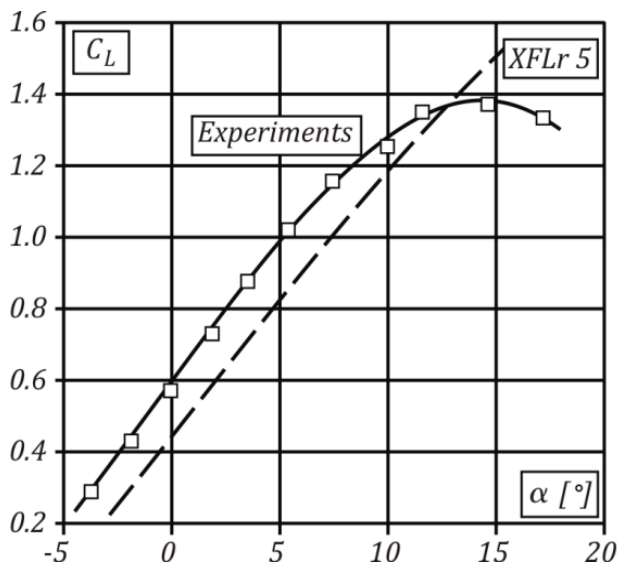

b). $C l(\alpha)$-felhajtóerő az állásszög függvényében

\section{Következtetések}

A repülőgép előzetes aerodinamikai számitásai, AAA (Advanced Aircraft Analasys - DARcorporation [9]) és XFLr5
[8] elemző programok eredményeire alapoz.

A becsült számítógépes és szélcsatorna tesztek eredményei a 6 . ábrán követhetök. A számítógépes softwerek és szélcsatorna tesztek közti eltérés $\approx 10 \%$.

A kezdetleges szélcsatorna kísérletek eredményei alapján a repülögép aerodinamikai teljesítménye $\approx 15.0 \%$-al magasabb a jelenlegi legjobb könnyü sportrepülőgépekhez viszonyítva.

A repülő gyártási előkészületeinek érdekében egy 1/4 mértékaranyú kísérleti repülömodell repülési kísérleteire fog sorkerülni.

\section{Szakirodalmi hivatkozások}

[1] EASA, Certification Specification and Acceptable Means of Compliance for Light Sport Aeroplanes, CS-LSA, European Aviation Safety Agency, 2013

[2] Roskam J., Airplane Design, Part I. Preliminary Sizing of Airplanes, University of Kansas, 1985

[3] Angi N., Huminic.A, Preliminary design of a LSA aircraft using wind tunnel tests, INCAS Bulletin,

[4] Angi N., Udroiu R., Design of a LSA aircraft using advanced software, International Conference of Scientific Papers - AFASES 2015

[5] Huminic A., Huminic G., CFD Study Concerning the Influence of the Underbody Components on Total Drag for a SUV, SAE Technical Paper 2009-01-1157, 2009,

[6] Barlow J., Rae W., Pope A., Low-speed wind tunnel testing, Third Edition, USA, 1999.

[7] Grosu, I., Calculul și construcția avionului, Vol. I/II., Editura Didactică și pedagogică București, 1965

[8] XFlr5, http://www.xflr5.com/xflr5.htm

[9] DARcorporation, http://www.darcorp.com/Software/AAA/ 